\title{
Acetoacetyl CoA Thiolase Deficiency Presenting as Ketotic Hypoglycemia
}

\author{
J. V. LEONARD, B. MIDDLETON, AND J. W. T. SEAKINS
}

Departments of Child Health [J.V.L] and Clinical Biochemistry [J.W.T.S.], Institute of Child Health, London, and Department of Biochemistry [B.M], University of Nottingham Medical School, Nottingham, England

\begin{abstract}
We report two children who presented with hypoglycemia and metabolic acidosis in whom acetoacetylCoA thiolase (EC 2.3.1.9) measured in fibroblast homogenates was deficient. Deficiency of this enzyme is normally associated with urinary excretion of 2-methylacetoacetate and in one child the urinary excretion of 2-methylacetoacetate, 2-methyl-3-hydroxybutyrate, and tiglylglycine was raised. By contrast, in the other child, the urinary excretion of these metabolites was very low even during ketoacidosis and following an isoleucine load. We suggest that this could be due to deficiency of the extrahepatic isoenzyme, a defect that may be responsible for some of the cases of "ketotic hypoglycemia." (Pediatr Res 21: 211-213, 1987)
\end{abstract}

\section{Abbreviations}

2MAA, 2-methylacetoacetate

2MOHB, 2-methyl-3-hydroxybutyrate

TG, tiglylglycine

GC-MS, gas chromatography-mass spectrometry

Deficiency of the enzyme $\beta$-ketothiolase has been postulated in a number of patients who presented with metabolic acidosis (McKusick 20375). In all cases (1) the diagnosis initially was suspected because of the presence of urinary metabolites derived from the breakdown of isoleucine, i.e. $2 \mathrm{MOHB}, 2 \mathrm{MAA}$, and TG. During episodes of ketoacidosis there usually is markedly increased excretion of these metabolites, and these can still be detected in the urine while the patients are well. The enzyme responsible for the cleavage of $2 \mathrm{MAA}$ is the mitochondrial thiolase (EC 2.3.1.9) which has a high specificity for acetoacetyl$\mathrm{CoA}$ and 2-methylacetoacetyl-CoA and is activated by potassium ions $(1,2)$. This enzyme also is necessary for utilization of ketone bodies which are responsible for cleaving acetoacetyl $\mathrm{CoA}$ to form acetyl CoA in extrahepatic tissues (3).

We describe two children who presented with hypoglycemia and metabolic acidosis, in whom the activity of potassiumactivated acetoacetyl CoA thiolase was found to be deficient. In one child the character metabolites, $2 \mathrm{MAA}, 2 \mathrm{MOHB}$, and TG were present in the urine. In the other child they were low even during ketoacidosis and following an isoleucine load.

\section{METHODS}

Urine $(2 \mathrm{ml})$ plus internal standard (undecanedioic acid) was acidified with $0.2 \mathrm{ml} 12 \mathrm{M}$ hydrochloric acid, saturated with sodium chloride and then extracted with ether $(2 \times 20 \mathrm{ml})$ using

Received January 15. 1985: accepted October 9.1986

Address for correspondence and reprints Dr. J. V. Leonard, Department of Child Health, Institute of Child Health. 30 Guilford Street. London, WC1N 1EH. UK. a vortex mixer, and centrifugation. Triethylamine $(0.5 \mathrm{ml})$ was added to the combined ether extracts to prevent loss of volatile acids and the solution taken to dryness in a rotary evaporator. An aliquot of residue, dissolved in isopropanol together with the external standards $\left(\mathrm{C}_{22}, \mathrm{C}_{26}\right.$, and nonadecanoic acid) was taken to dryness in a reaction vial prior to conversion to TMS derivatives (pyridine/BSTFA 1:1 v/v). Aliquots were chromatographed on packed columns of OV 101 or OV $17(10 \%)$ using temperature programming ( 70 to $315^{\circ}$ at $8 / \mathrm{min}$ ).

Appropriate samples were further examined by GS-MS (Lynes G, Queen Elizabeth Hospital, London). For these samples the extraction procedure was modified by using ethylacetate as well as ether (each $1 \times 20 \mathrm{ml}$ ), and then continuing as above. The sensitivity was of the order $1 \mathrm{mg}$ acid/g creatinine. Quantitation was by GC, confirmation of identity by GC-MS. Plasma 3hydroxybutyrate was determined by the fluorimetric method of Lloyd et al. (10).

Fibroblast cultures were maintained in Hams F10 containing $12 \%(\mathrm{v} / \mathrm{v})$ fetal calf serum, penicillin, and streptomycin. Cells were harvested by trypsinization and washed twice in phosphatebuffered saline and stored as pellets at $-80^{\circ} \mathrm{C}$ until assayed.

Extracts of cells were prepared by suspending the frozen and thawed pellets in $0.5 \mathrm{ml}$ of $100 \mathrm{mM}$ Tris sulfate $\mathrm{pH} 8.1$ containing $1 \mathrm{mM}$ dithiothreitol. The suspensions were sonicated (Kelly Sonibath) for $2 \mathrm{~min}$ at $0^{\circ} \mathrm{C}$ and Triton $\mathrm{X}-100$ was added to a final concentration of $0.5 \%(\mathrm{w} / \mathrm{v})$.

Homogenates were assayed for protein, for the mitochondrial marker citrate synthase, and for 3-ketoacyl-CoA thiolase activity as previously described (1). The 3-ketoacyl-CoA thiolase activity was determined with three different 3-ketoacyl-CoA substrates, all at $10 \mu \mathrm{M}$, in the presence of $50 \mathrm{mM}$ potassium ions. In the case of 3-ketoacyl-CoA as substrate assays were also carried out in a $\mathrm{K}^{+}$-free medium to determine the stimulation by potassium ions. Succinyl CoA:acetoacetate CoA transferase (CoA transferase) was determined by observing the decrease in acetoacetylCoA concentration ( $40 \mu \mathrm{M}$ in cell) at $303 \mathrm{~nm}$ after the addition of sodium succinate $(50 \mathrm{mM}$ in cell) to a $1.0 \mathrm{ml}$ system containing homogenate $25 \mathrm{mM} \mathrm{MgSO}_{4}$ and $100 \mathrm{mM}$ Tris sulphate $\mathrm{pH} 8.1$ at $30^{\circ} \mathrm{C}$. The $\mathrm{E}_{\mathrm{mm}}$ under these conditions was 16.9 (2). Control (normal) cell homogenates were assayed concurrently and all determinations were made in duplicate.

\section{CASE REPORT}

Case 1. A Caucasian girl, the first child of unrelated, healthy parents, thrived and made normal developmental progress until the age of 10 months. She then developed gastroenteritis and was treated with clear fluids. The following morning she was drowsy with a poor peripheral circulation and marked tachypnea. She was hypoglycemic (blood glucose $0.6 \mathrm{mmol} / \mathrm{liter}$ ) with a metabolic acidosis (pH 7.09, $\mathrm{pCO}_{2} 13.5 \mathrm{~mm} \mathrm{Hg}$, standard bicarbonate $5.4 \mathrm{mmol} /$ liter) and marked ketonuria. Treatment with intravenous glucose and sodium bicarbonate was started but she dete- 
riorated and became semicomatose and dehydrated. Her eyes deviated to the right with the signs of a left hemiplegia. The metabolic acidosis persisted with marked ketonuria and hypernatremia (plasma sodium $154 \mathrm{mmol} / \mathrm{liter}$ ). Plasma ammonium was $27 \mu \mathrm{mol} / \mathrm{liter}$. Clotting studies and examination of the cerebrospinal fluid were normal. After another $24 \mathrm{~h}$ of treatment with intravenous fluids and bicarbonate-based peritoneal dialysis, the acidosis and hypernatremia had been corrected. However, she remained hypotonic and unresponsive. Two days after admission she had a series of right-sided focal convulsions. Eight days after admission she had regained consciousness but was restless with choreoathetoid movements of her lips and arms. She had marked hypotonia of her trunks and limbs, reduced tendon jerks, and extensor plantar responses. By the age of 15 months, although she still had some truncal ataxia, she was taking one or two steps unaided, used at least two words with meaning, and had a mature grip in the right hand.

Case 2. A Caucasian girl was well up to the age of 15 months. Following mild febrile illness she became progressively more drowsy with labored respirations. On admission she was comatose but responded to painful stimuli. She was hypoglycemic with a metabolic acidosis and marked ketonuria. Endotracheal intubation and mechanical ventilation were necessary for 5 days. She was treated with intravenous glucose and sodium bicarbonate and made complete recovery.

\section{RESULTS}

Urine organic acids. During the acute illness case 1 showed only massive excretion of 3 hydroxybutyrate. In case 2 2MAA, $2 \mathrm{MOHB}$, and TG also were present (Table 1).

A defect in ketone body utilization was suspected in case 1 and further investigations were done on this child once she had recovered from the acute illness and was reestablished on milk feeds.

\section{INVESTIGATIONS ON CASE 1}

Response to fasting. Two fasts were done lasting 14 and $18 \mathrm{~h}$, respectively. During these fasts there was a rapid rise in plasma 3-hydroxybutyrate and a gradual fall in plasma glucose with no rise in blood lactate (Fig. 1). Urine collected at the end of the longer fast contained a huge quantity of 3-hydroxybutyrate but only traces of $2 \mathrm{OHB}$ and of the intermediates of the breakdown of isoleucine.

Loading tests. Isoleucine $(100 \mathrm{mg} / \mathrm{kg})$. The blood glucose and

Table 1. Urine organic acids during acute illness and during subsequent investigations ( $\mathrm{mg} / \mathrm{g}$ creatinine)

\begin{tabular}{|c|c|c|c|}
\hline & 3-Hydroxybutyric & $2 \mathrm{MOHB}$ & Others \\
\hline \multicolumn{4}{|l|}{$\overline{\text { Case } 1}$} \\
\hline $\begin{array}{c}\text { First admission } \\
\qquad(\text { day } 2)\end{array}$ & 7216 & Trace & Adipic 124 \\
\hline $\begin{array}{c}\text { First admission } \\
\text { (day 10) }\end{array}$ & 335 & Trace & \\
\hline $\begin{array}{c}\text { Prolonged fast } \\
(18 \mathrm{~h})\end{array}$ & 18580 & Trace & $\begin{array}{l}\text { Adipic } 60 \\
\text { acetoacetate } \\
\text { gross }\end{array}$ \\
\hline \multicolumn{4}{|l|}{ Leucine load } \\
\hline $\operatorname{Pre}(6 \mathrm{~h}$-fast) & ND* & ND & \\
\hline Post $(2.5 \mathrm{~h})$ & 55 & ND & \\
\hline \multicolumn{4}{|l|}{ Isoleucine load } \\
\hline $\operatorname{Pre}$ (6-fast) & ND & ND & \\
\hline Posi $(2 \mathrm{~h})$ & ND & ND & \\
\hline \multicolumn{4}{|l|}{ Case 2} \\
\hline & & & $\begin{array}{ll}\text { Lactate } & 220 \\
\text { TG } & 200\end{array}$ \\
\hline During admission & 4000 & $\dagger$ & $\begin{array}{l}\text { Acetoacetate gross } \\
\text { 2-Me acetoacetate } \\
\text { present }\end{array}$ \\
\hline Age 14 mo (well) & ND & 200 & TG $\quad 130$ \\
\hline
\end{tabular}

* None detected by GC-MS (less than $1 \mathrm{mg} / \mathrm{g}$ creatinine).

+ If present obscured by gross peak of 3-hydroxybutyrate.

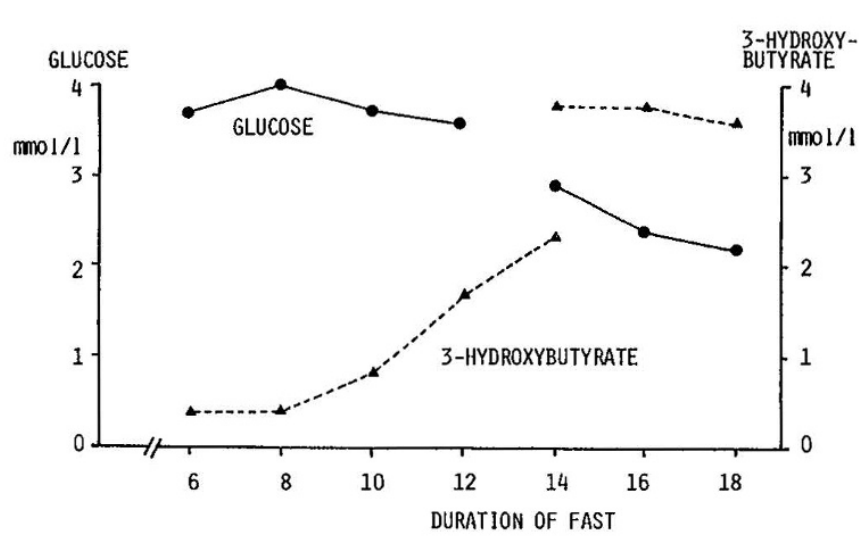

Fig. 1. Case 1-blood glucose and 3-hydroxybutyrate concentrations during fasting. These results were obtained during two fasts, one lasting $14 \mathrm{~h}$ and the other $18 \mathrm{~h}$.

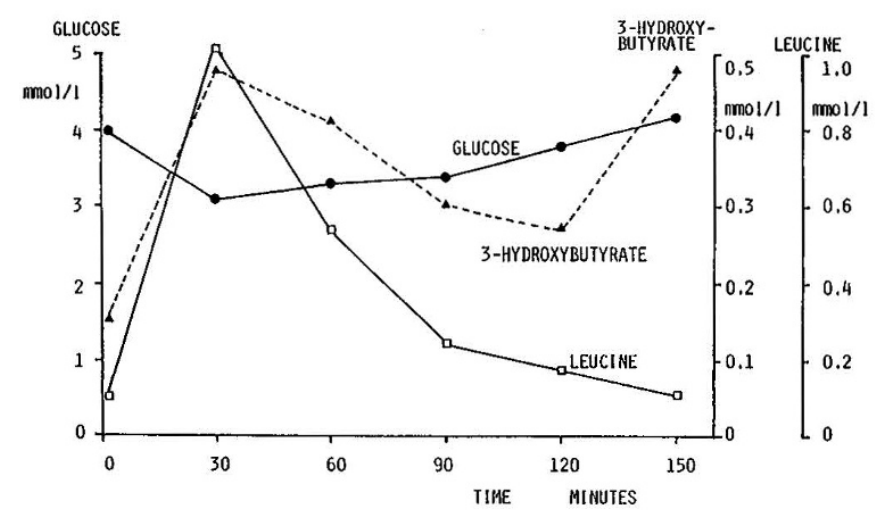

Fig. 2. Case 1-blood glucose, blood 3-hydroxybutyrate, and plasma leucine concentrations after a leucine load of $100 \mathrm{mg} / \mathrm{kg}$.

3-hydroxybutyrate concentrations did not change during this test, which was done after a 6 -h fast. No abnormal organic acids were detected in the urine collected after this load (Table 1).

Leucine $(100 \mathrm{mg} / \mathrm{kg})$. Following the leucine there was a transient fall in glucose and a rise in 3-hydroxybutyrate (Fig. 2). Urine organic acids before the load were normal but contained 3-hydroxybutyrate $(55 \mathrm{mg} / \mathrm{g}$ creatinine) and 3-hydroxyisovaleric acid $(162 \mathrm{mg} / \mathrm{g}$ creatinine) after the load.

Glucagon test. A standard glucagon stimulation test (4) was normal with a maximum rise in blood glucose of $3.5 \mathrm{mmol} / \mathrm{liter}$.

Enzyme assays in cultured skin fibroblasts. The activity of 3ketoacyl-CoA thiolase was determined using acetoacetyl-CoA (the substrate common to all the $\beta$-ketothiolases) in the presence and absence of $\mathrm{K}^{+}$ions (Table 2). In the absence of $\mathrm{K}^{+}$ions the activity was similar in the patient and the controls. However, in the presence of $\mathrm{K}^{+}$there was 3 -fold stimulation in the activity in control lines but no change in the patients' cells. This indicates that the $\mathrm{K}^{+}$activated mitochondrial acetoacetyl thiolase is absent (2). This enzyme also uses 2-methylacetoacetyl-CoA as substrate [unlike all other 3-ketoacyl-CoA thiolase enzymes (1)] and with this substrate, no significant activity was found (within assay sensitivity limits of $30 \mathrm{pmol} / \mathrm{min}$ ) in homogenates of patient 1 or 2 . This thiolase assay was repeated at $40 \mu \mathrm{M} 2$-methylacetoacetyl CoA but no significant rate was detected at this higher concentration in cells of either patient. The other mitochondrial 3-ketoacyl-CoA thiolase (EC 2.3.1.16) is capable of using a wide range of straight-chain 3-ketoacyl-CoA substrates. Its activity was assayed using 3-ketohexanoyl-CoA and was normal (Table 2).

The mitochondrial matrix enzyme citrate synthase in fibroblast homogenates of the patient was within the range of values of the control lines (Table 2). In cells of patient 1 the activity of succinyl CoA:acetoacetate transferase was $69 \%$ of the mean value of normals which, although low, was not outside the reference 
Table 2. Enzyme activities measured in homogenates of cultured skin fibroblasts (nmol of substrate removed min $^{-1} \mathrm{mg} \mathrm{protein}^{-1}$ )

3-ketoacyl-CoA thiolase activities with different substrates

\begin{tabular}{|c|c|c|c|c|c|c|c|}
\hline \multirow[b]{2}{*}{ Subjects } & \multicolumn{2}{|c|}{ Acetoacetyl-CoA } & \multirow[b]{2}{*}{ Ratio* } & \multirow[b]{2}{*}{$\begin{array}{l}\text { 2-Methylaceto- } \\
\text { acetyl-CoA }\end{array}$} & \multirow[b]{2}{*}{$\begin{array}{l}\text { 3-ketohex- } \\
\text { anoyl-CoA }\end{array}$} & \multirow{2}{*}{$\begin{array}{c}\text { Succinyl } \mathrm{CoA} \\
\text { transferase } \\
\text { activity }\end{array}$} & \multirow{2}{*}{$\begin{array}{c}\text { Citrate } \\
\text { synthase } \\
\text { activity }\end{array}$} \\
\hline & With $\mathrm{K}^{+}$ & $\begin{array}{c}\text { In absence } \\
\text { of } \mathrm{K}^{+}\end{array}$ & & & & & \\
\hline Patient 1 & 19.4 & 19.3 & 1.0 & $<3.0$ & 70.7 & 26.5 & 102.7 \\
\hline 2 & 8.3 & 8.3 & 1.0 & $<1.0$ & 33.8 & 42.0 & 87.4 \\
\hline $\begin{array}{l}\text { Controls } \\
( \pm \text { SEM })\end{array}$ & $\begin{array}{r}58.6 \\
( \pm 10.9)\end{array}$ & $\begin{array}{c}19.4 \\
( \pm 3.7)\end{array}$ & 3.1 & $\begin{array}{c}57.2 \\
( \pm 8.5)\end{array}$ & $\begin{aligned} & 80.5 \\
&( \pm 26.4)\end{aligned}$ & $\begin{array}{c}38.2 \\
( \pm 4.8)\end{array}$ & $\begin{array}{r}122.5 \\
( \pm 18.8)\end{array}$ \\
\hline
\end{tabular}

* Ratio of activity with acetoacetyl CoA in the presence of $\mathrm{K}^{+}$divided by rate with the same substrate in the absence of $\mathrm{K}^{+}$.

range (Table 2). When expressed relative to citrate synthase activity (both enzymes are in the mitochondrial matrix) it was $81 \%$ of the control value which is well within the reference range.

\section{DISCUSSION}

In mammalian cells there are four thiolases, one cystosolic, two mitochondrial, and one peroxisomal $(2,5)$. The cystosolic enzyme is involved in cholesterogenesis, is specific for acetoacetyl-CoA, and is not activated by potassium ions. One of the mitochondrial enzymes (EC 2.3.1.16) and the peroxisomal thiolase have broad specificity and are responsible for thiolysis of long-chain 3-ketoacyl-CoA esters. The other mitochondrial enzyme (EC 2.3.1.9) is activated by $\mathrm{K}^{+}$and is specific for acetoacetyl- and 2-methylacetoacetyl-CoA. Complete absence of this enzyme would result in a defect in ketone body utilization and also a failure in the breakdown of 2-methylacetoacetyl-CoA derived from isoleucine. The accumulation of isoleucine metabolites 2MAA, 2MOHB, TG have led to the identification of the disorder usually called $\beta$-ketothiolase deficiency, but only recently has the enzyme been shown to be defective in these patients (1).

Both children in the present study had a deficiency of the mitochondrial $\mathrm{K}^{+}$-dependent acetoacetyl-CoA thiolase and were unable to metabolize 2-methylacetoacetyl-CoA in fibroblast extracts. In neither case was the defect due to a raised $\mathrm{K}_{\mathrm{m}}$ for 2methyl-acetoacetyl-CoA. Patient 2, when ill, excreted a gross excess of $30 \mathrm{HB}$ in urine in addition to TG and 2MAA. TG and $2 \mathrm{MOHB}$ were also present when she was well. This is typical of the $\beta$-ketothiolase deficiency. By contrast patient 1 excreted only "normal" ketone bodies when ill. After a short fast there was a rapid rise in plasma concentrations of 3-hydroxybutyrate with large quantities in the urine. The leucine load led to a rise in plasma-3-hydroxybutyrate concentrations as the amino acid was catabolized. The concentrations then fell only to rise again at the end of the study as the period of fast extended. We concluded that she had a defect in ketone body utilization. Since only traces of $2 \mathrm{MOHB}$ could be detected in the urine when she was ill and none after isoleucine loading, a tentative diagnosis of succinylCoA:acetoacetate CoA-transferase was suggested. However, measurements of enzyme activities in cultured fibroblasts showed that she had defective mitochondrial acetoacetyl-CoA thiolase. The residual activity toward acetoacetyl-CoA in homogenates of the patients' fibroblasts mainly represents the cytoplasmic isoenzyme of acetoacetyl-CoA thiolase which is unaffected by $\mathrm{K}^{+}$ions and has no activity toward either 2-methylacetoacetyl-CoA or 3ket J-hexanoyl-CoA (1)

The enzyme defect in case 1 appears to be identical to that in case 2 and in other patients with this disorder $(1,6,7)$ but in case 1 the defect is only manifest by the apparent reduced utilization of ketone bodies. The explanation of this remains uncertain but in the rat there are two isoenzymes with different physical properties (11). It has been proposed that the hepatic form of the enzyme is important for acetoacetyl-CoA synthesis during ketogenesis while the extrahepatic form is necessary for acetoacetate utilization (11). Absence of the extrahepatic isoenzyme alone would leave ketogenesis unaffected and since the liver enzyme is capable of rapid breakdown of $2 \mathrm{MAA}$, intermediates of breakdown of isoleucine may not accumulate. However, the variability in excretion of isoleucine intermediates could be due to competition between acetoacetyl-CoA and 2-methylacetoacetyl-CoA for cleavage by the hepatic isoenzyme. Such competition occurs even in individuals with ordinary ketoacidosis who have been found to excrete small amounts of $2 \mathrm{MOHB}$ in addition to normal ketone bodies (12).

As no characteristic metabolites were found in case 1 she could have been labeled as having "idiopathic ketotic hypoglycemia." For this reason we would suggest that acetoacetyl-CoA thiolase deficiency might be more common than is currently recognized. Patients with idiopathic ketotic hypoglycemia do not restrict glucose utilization during fasting despite hypoglycemia $(8,9)$ and the respiratory quotient remains higher than controls (9). This could be due to a defect in ketone body utilization and a defect of the extrahepatic mitochondrial acetoacetyl-CoA thiolase may explain the findings in some of these children.

Acknowledgments. The authors thank Dr. H. Scott and Dr. P. $\mathrm{R}$. Clay for referring the patients.

\section{REFERENCES}

1. Middleton B, Bartlett K 1983 The synthesis and characterization of 2-methylacetoacetyl-COA and its use in the identification of the site of the defect in 2-methylacetoacetic and 2-methyl-3-hydroxy-butyric aciduria. Clin Chim Acta 128:291-305

2. Middleton B 1973 The oxoacyl-CoA thiolases of animal tissues. Biochem J 132:717-730

3. Williamson DH. Bates MW, Page MA. Krebs HA 1971 Activities of enzymes involved in acetoacetate utilization in adult mammalian tissues. Biochem $\mathrm{J}$ $121: 41-47$

4. Dunger DB. Lconard JV 1982 The value of the glucagon test in screening for hepatic glycogen storage disease. Arch Dis Child 57:384-389

5. Krahling GB. Tolbert NE 1980 Peroxisomal beta-ketothiolase. Arch Biochem Biophys 209:100-110

6. Schutgens RBH. Middleton B, Van der Blij JF, Oorthuys JWE, Veder HA, Vulsma T. Tegelaers WHH $1982 \beta$-Ketothiolase deficiency in a family confirmed by in vitro enzymatic assays in fibroblasts. Eur J Pediatr 139:3942

7. Middleton B. Gray RGF, Bennett MJ 1984 Two cases of $\beta$-ketothiolase deficiency: a comparison. J Inherited Metab Dis 7(suppl 2):131-132

8. Dahlquist G. Gentz. J. Hagenfeldt L. Larsson A, Low H, Persson B. Zetterstrom R 1979 Ketotic hypoglycaemia of childhood-a clinical trial of several unifying etiological hypotheses. Acta Paediatr Scand 68:649-656

9. Kerr DS. Stevens MCG. Picou DIM 1975 Estimation of fasting glucose flux in malnourished and hypoglycaemic children by constant infusion of ${ }^{13} \mathrm{C}$ glucose. 2nd Intcrnational Conference on Stable Isotopes. Argonne. IL. National Technical Information Services. Springfield, VA, pp 336-343

10. Lloyd B. Burrin J. Smythe P. Alberti KGMM 1978 Enzymic fluorimetric continuous flow assays for blood glucose, lactate, pyruvate, alanine, glycerol and 3-hydroxybutyrate. Clin Chem 24:1724-1729

11. Middleton B 1978 Enzymatic aspects of ketone body metabolism: the role of mitrochondrial acetoacetyl CoA thiolase isoenzymes. In: Soling HD, Suefert CD (eds) Biochemical and Clinical Aspects of Ketone Body Metabolism. Georg Thiemc, Stuttgart, pp 1-9

12. Landaas S 1975 Accumulation of 3-hydroxyisobutyric acid. 2-mcthyl 1-3hydroxybutyric acid and 3-hydroxyisobutyric acid in ketoacidosis. Clin Chem Acts 64:143-154 